\title{
Who Are the Homeless? Centering Anti-Black Racism and the Consequences of Colorblind Homeless Policies
}

\author{
Earl James Edwards
}

check for updates

Citation: Edwards, Earl James. 2021. Who Are the Homeless? Centering Anti-Black Racism and the Consequences of Colorblind Homeless Policies. Social Sciences 10: 340. https://doi.org/10.3390/ socsci10090340

Academic Editor: Michele Wakin

Received: 18 July 2021

Accepted: 2 September 2021

Published: 13 September 2021

Publisher's Note: MDPI stays neutral with regard to jurisdictional claims in published maps and institutional affiliations.

Copyright: (C) 2021 by the author. Licensee MDPI, Basel, Switzerland. This article is an open access article distributed under the terms and conditions of the Creative Commons Attribution (CC BY) license (https:// creativecommons.org/licenses/by/ $4.0 /)$.
School of Education and Information Studies, University of California, Los Angeles, Los Angeles, CA 90095, USA; eedwards02@g.ucla.edu

\begin{abstract}
Since first becoming a major social issue in the 1980s, homelessness has been a racialized problem in the United States. Its disproportionate impact on Black Americans is primarily driven by structural racism and the limited housing and employment opportunities for Black Americans. The first major federal legislation to address the needs of the United States' homeless population-the Stewart B. McKinney-Vento Homeless Assistance Act of 1987 omitted the root causes of Black housing instability, thereby proving ineffective at mitigating Black homelessness. As a result, Black Americans remain disproportionately impacted today. In addition to being neglected by the McKinney-Vento Homeless Assistance Act, Black men and women experiencing homelessness are more likely to be discriminated against than any other racial group. For example, Black men are more likely to be arrested than anyone else, and Black women are the most likely to experience hyper-surveillance. This paper uses the Public Identity Framework to argue that in the 1980s, advocates and opponents of homeless legislation created two contradictory public personas to shape public discourse and policies for the homeless. A colorblind public persona was used to pass the McKinney-Vento Homeless Act; meanwhile, the public persona of the "underclass" was used to criminalize and shame the homeless. Both personas operated concurrently to create a dual public identity for the homeless that influenced policy and ultimately harmed Black people.
\end{abstract}

Keywords: homelessness; McKinney-Vento; homeless policy; public identity; black homelessness

\section{Introduction}

Though it is rarely described in this way, homelessness is a racialized problem in the United States. Housing and Urban Development's 2021 Annual Homeless Assessment Report (AHAR) to Congress found that Black people accounted for 40 percent of 550,000 reported individuals experiencing homelessness in the country, despite composing only 13 percent of the U.S. population. Black people are one of the only racial groups disproportionately impacted by homelessness in the country. Analysis from the National Alliance to End Homelessness (2019) found that Black Americans were more likely to experience homelessness than White Americans in every state in the U.S. regardless of their population size. For example, while Black people make up just $2 \%$ and $18 \%$ of the Maine and New York total population, respectively, and Black people are ten times more likely to experience homelessness than White people in each respective state. Further, the alarming disproportionality of Black people in the homeless population has been a consistently documented trend since the first AHAR report (Khadduri et al. 2007). Similarly, a recent study found that one in six Black Americans between 51 and 68 years old self-disclosed experiences of homelessness, a rate three times higher than White Americans in the same age group (Fusaro et al. 2018).

Although research from the 1980s and 1990s documents the disproportionate rates of homelessness among Black people (Hopper and Milburn 1996), scholars have only recently started examining and addressing racial disparities in the homeless population (Aviles de Bradley 2015; Edwards 2020; Olivet et al. 2021; Paul et al. 2020). As such, scholars have 
yet to thoroughly theorize how racial dynamics have shaped social policy and research on homelessness. This paper addresses the gap in the literature via an examination of homelessness through the conceptual lens provided by Hancock's (Hancock 2003) Public Identity Framework. The paper applies Public Identity Framework to policy discourse around the landmark homelessness policy the McKinney-Vento Homelessness Assistance Act.

Hancock, a political scientist interested in intersectional theory's impact on public policy, developed the Public Identity Framework to analyze how public discourse and public perception are manipulated and weaponized to push policy agendas. The central example she uses to examine this phenomenon was the "welfare queen" trope. The "welfare queen" is a mythical narrative first introduced in the 1970s and later weaponized by President Ronald Reagan's administration in the 1980s to impact social welfare reform. The goal of the welfare queen narrative was to label poor, Black women and depict them as "lazy, baby-making system abusers" (Hancock 2003, p. 39). The intersectional identity of being Black, woman, and low-income was thus exploited by politicians and policy influencers to make the general public morally against social welfare programs and favor legislation to cut welfare benefits (Hancock 2003).

As a result of the welfare-queen narrative, the country's sentiments about government assistance shifted from empathy towards working-class citizens who needed federal support to disgust for poor, Black women exploiting the government (Hancock 2003). While white working-class families and low-income families were still the primary beneficiaries of welfare programs, the new public disgust toward social welfare programs and those associated with them convinced the general public to vote against their economic interest and dramatically cut social welfare programming.

The construction of public personas such as the welfare queen manipulates public discourse to shape perceptions and ultimately influence policy decisions. This paper argues that the construction of public personas has similarly influenced perceptions and policies geared towards individuals experiencing homelessness. While the welfare queen public persona was heavily racialized, not all public personas require such racialization. In fact, in the 1980s, two contradictory public personas were created to shape public discourse and policies for the homeless-one of which was colorblind. The colorblind "everyday people" public persona associated with homelessness was used to pass the McKinney-Vento Homeless Assistance Act (MVA); meanwhile, the racialized "underclass" public persona was used to criminalize and shame the homeless. Both personas operated concurrently to create a dual public identity for homelessness that influenced homeless policy and ultimately harmed Black people experiencing homelessness.

The following section of this paper provides a brief overview of the McKinney-Vento Homeless Assistance Act. Then, I define Public Identity and discusses how the framework was used to analyze welfare reform and assert its effectiveness as an analytic tool for examining homelessness. The subsequent section uses Public Identity as a lens to examine the two public personas created for people experiencing homelessness and shows how they operated concurrently to make Black Americans more susceptible to homelessness and hyper-criminalization than any other racial-ethnic group, a framework that I call a Dual-Public Identity. The last section offers critical takeaways from the dual public identity of homelessness and provides an alternative strategy for policy.

\section{The McKinney Vento Homeless Assistance Act}

The Stewart B. McKinney-Vento Homeless Assistance Act of 1987 (MVA), originally introduced as the "The Urgent Relief for the Homeless Act", was the first comprehensive federal legislation to address the needs of the United States' homeless population. Prior to MVA, the federal government did not consider homelessness as issue for federal intervention. In 1983, Congress responded to the increased visibility of homelessness in the U.S. by treating the crisis as a temporary issue and appropriating emergency food and shelter funds through the Federal Emergency Management Agency (FEMA) (Foscarinis 1996; 
Hombs 1994). The emergency response was not codified through legislation and relied heavily on voluntary organizations to dispense the funds. The passing of MVA expanded upon this initial response to homelessness by establishing a comprehensive emergency response.

\subsection{Key Provisions of The Act}

MVA authorized just over one billion dollars to fund 15 homeless assistance programs across eight different federal agencies between 1987-1988 (Foscarinis 1996). The programs included health care, community based mental health services for homeless individuals who are chronically mentally ill; emergency shelter; transitional housing; job training; permanent housing for handicapped homeless persons'; grants for groups to renovate, convert, purchase, lease, or construct facilities. Most MVA funds went to Housing and Urban Development to establish or expand programs focused on emergency housing. In 1987, MVA allocated over \$200 million in emergency shelter grants and transitional housing funding to states, counties, and cities, to house individuals experiencing homelessness.

MVA also established the Interagency Council on the Homeless within the executive branch, known as the United States Interagency Council on Homelessness (USICH) today. USICH served an independent establishment to assess the effectiveness of federal activities and programs designed to assist people experiencing homelessness and promote coordination among federal agency programs, state and local governments, and public and private sector organizations. USICH was also responsible for preparing an annual report to the president and congress assessing the needs of people experiencing homelessness and offering policy and administrative recommendations.

In addition to providing emergency housing and food needs to people experiencing homelessness, MVA also established educational protections for children experiencing homelessness in public schools. MVA states that students experiencing homeless must have access to free, appropriate public education and barriers to school enrollment should be reviewed and revised. This provision was critical for children displaced by homelessness and not enrolled in school due to residency challenges, lack of immunization records, or slow transference of academic records between school districts.

\subsection{Targeted Population}

MVA was designed to address the urgent needs of all individuals and families experiencing homelessness and names specific target populations at higher risk. Title I of MVA states, "The Nation faces an immediate and unprecedented crisis due to the lack of shelter for a growing number of individuals and families, including elderly persons, handicapped persons, families with children, Native Americans, and veterans" (The McKinney-Vento Homeless Assistance Act of 198742 U.S.C. § 11431, et seq 1987). The listed populations are embedded within the mandates of entire act as MVA outlines separate programs, initiatives, and funding requirements for supporting each of the target groups. For example, states, counties, or cities seeking funds, were required to develop a comprehensive homeless assistance plan that explicitly states how they planned to meet the needs of elderly persons, handicapped persons, families with children, and veterans. Similarly, Native tribes were earmarked a small percentage of funds under the job training and emergency community services homeless programs.

\subsection{McKinney Vento Legacy}

A landmark social policy victory, the act marked the first-time that the federal government recognized homelessness as a public policy issue requiring federal intervention. The victory felt even more pronounced because MVA was passed during President Ronald Reagan's administration with bipartisan support. As previously mentioned, Reagan's Administration lead the country's largest divestment in social welfare programs and fought adamantly against the notion that homelessness was a systemic issue in need of a federal response. Thirty years later, today, many MVA programs still exist and have been expanded 
upon. For example, MVA education provision is still the most comprehensive legislation supporting children and youth experiencing homelessness in schools.

Despite the policy's immediate and sustained impact, MVA was underfunded and the programs focused heavily on providing emergency housing versus addressing the root causes of homelessness from their purview of affordable housing, well-paying jobs, and social services (Foscarinis 1991, 1996). MVA also omitted Black people as a target subpopulation experiencing homelessness. This paper uses Public Identity Framework to analyze the framing of homelessness as a problem in the U.S. and how such framing led to the passing of the McKinney-Vento Homeless Assistance Act.

\section{Public Identity as a Theoretical Framework}

The Public Identity Framework (Hancock 2003) utilizes controlling images (Collins 1990) and cultural narratives (Lubiano 1992) to construct and manipulate public perceptions that impact discourse and ultimately influence policy decisions. Building upon Kimberlé Crenshaw's (Crenshaw 1989, 1991) concept of intersectionality, which acknowledges the negative impact of laws and policies that exclude Black women, Public Identity ensures that intersectional identity markers are combined to construct stereotypes that intentionally target marginalized citizens. It is important to note that a public identity functions differently than the traditional stereotype. Traditional stereotypes inaccurately categorize groups of people by characteristics and passively overgeneralize such attributes to the point that they become common knowledge (Mackie 1973). A public identity, however, is (1) a collection of behavioral and moral traits, (2) explicitly created for political leverage, and (3) functions on both a macro and micro level to filter all related information (Hancock 2003). While policymakers commonly use stereotypes to frame policy arguments, public personas are purposely created by policymakers and influential interest groups to push public policy agendas. Once a public persona is created, it becomes challenging to disconnect values and moral judgments from the people initially associated with the persona. The public persona is disseminated through political discourse, mainstream media and news outlets, and academic institutions that reinforce the narrative of said persona. Furthermore, the policies and laws resulting from a particular public persona never stop either benefiting or marginalizing the group of people associated with it.

\section{The "Welfare Queen" as an Example of a Public Persona}

Hancock (2003) uses Public Identity as an analytic tool for examining welfare reform in the 1980s and 1990s. Hancock (2003) describes public identity as the bridge between the public sphere and individual citizens and argues that creating and disseminating the "welfare queen" as a public identity was a critical factor in the termination of many social welfare programs. The "welfare queen" public perception did not go uncontested. The National Welfare Rights Organization was founded in the 1970s by Black, low-income, single mothers who challenged the public persona of the welfare queen. The organizers used public demonstrations and their image as single, Black, low-income women working hard to impact political change. However, the organization was overlooked by mainstream media and politicians in large part due to its participants' intersectional identities of being poor, woman, and Black. They did not receive support from any general public sections (including the major male, black civil rights organizations). They thus were unable to insert their message into the public discourse with the same effectiveness as the Reagan Administration. Despite NWRO efforts, the "welfare queen" became the dominant public persona, and it was weaponized to elicit disgust on not just political issues about welfare benefits, but for issues such as reproduction rights (Roberts 1997) and child neglect (Roberts 2011).

Intersectional approaches such as Public Identity, while underutilized, are critical to understanding public policy (Hancock 2003). Homelessness, for example, is a pressing social issue that benefits from such analysis, as public identity politics have deeply impacted it. In the 1980s, the tension between homeless advocates and the Republican administration 
developed over the public identity of the homeless. While homeless advocates attempted to make a colorblind public identity, with white middle-class Americans (often with mental illness) serving as the default face of homelessness, the Republican administration and thought leaders fought to make the term "homeless" synonymous with the "Black underclass". Creating a public identity for homelessness was important because who was affected by homelessness would shape the political goals, public discourse, and the ideological justification for government support (Hancock 2003; López 2015). In the following section, I will use public identity as a framework for examining homelessness and the McKinney-Vento Homeless Assistance Act.

\section{Competing Public Personas for the Homeless}

Today "homeless" is a term used casually to refer to individuals who do not have shelter. However, the term "homeless" was rarely used in public discourse before the 1980s. Using a digital archive of U.S. newspapers, I searched the term "homeless" in four prominent newspapers in major cities where homelessness has historically been a significant public issue-Boston, Chicago, New York, and Los Angeles. I narrowed my search to articles between 1955 and 1990 to capture the use of the term "homeless" before MVA and immediately after. Table 1 shows that between 1975 and 1990, the frequency of the term "homeless" increased by $1380 \%$ across these four major newspapers. As the term "homeless" gained popularity in public discourse, what constituted homelessness also started to shift. For example, in the 1950s, 1960s, and 1970s, individuals whom were considered homeless did not live on the streets, but in cheap hotels and dilapidated single-room occupancies (S.R.O.s) in skid rows throughout major cities (Cumming 1974; Rossi 1990). The transient population was commonly referred to as "vagrants," "tramps," "bums," "hobos," or "winos" and were generally perceived as white men in their 1950s, disconnected from family units and without a social home (Cumming 1974; Jencks 1995; Jones 2015; Levitas 1990; Rossi 1990).

Table 1. The frequency of the word "homeless" in major newspapers between 1955-1995. Data were collected from an online digital archive of newspapers, Newspaper.com on 16 July 2021 using the search term "homeless".

\begin{tabular}{|c|c|c|c|c|c|}
\hline Years & Daily News & Los Angeles Times & Chicago Tribune & The Boston Globe & Combined Total \\
\hline 1955 & 1075 & 179 & 197 & 247 & 1698 \\
\hline 1960 & 675 & 169 & 156 & 226 & 1226 \\
\hline 1965 & 582 & 227 & 167 & 205 & 1181 \\
\hline 1970 & 844 & 223 & 198 & 233 & 1498 \\
\hline 1975 & 372 & 256 & 167 & 211 & 1006 \\
\hline 1980 & 956 & 378 & 199 & 239 & 1772 \\
\hline 1985 & 3212 & 1896 & 431 & 783 & 6322 \\
\hline 1990 & 4940 & 5985 & 2315 & 1655 & 14,895 \\
\hline $\begin{array}{l}\text { \% increase from } \\
1975 \text { and } 1990\end{array}$ & $1228 \%$ & $2238 \%$ & $1286 \%$ & $684 \%$ & $1380 \%$ \\
\hline
\end{tabular}

In the 1980s, the number of unhoused people increased, and the characteristics of the transient demographic shifted dramatically. In contrast to prior decades, the transient population in the 1980s was (1) literally living on the streets, (2) on average 20 years younger, (3) racially Black, and (4) inclusive of a growing number of women and children (Rossi 1990). Grassroots activists and researchers strategically referred to this new transient population as the "new homeless," thus appropriating and promulgating the terms "homeless" and "homelessness" into public and political discourse (Jones 2015). Additionally, it is essential to underscore that homelessness was a crisis specifically impacting large cities such as New York City, Los Angeles, Chicago, and Boston. Smaller cities, suburbs, and rural towns across the United States were less affected by homelessness, and many citizens had no contact with people living on the street. Thus, the dominant narratives disseminated to the majority of American citizens, who were oblivious to homelessness, through mainstream 
media would play a determining factor if policymakers would support a federal policy that did not directly impact them or their constituents (Levinson 2004).

\section{Public Identity A: A Colorblind Homeless Identity}

In an attempt to pass laws and policies to provide people experiencing homelessness with shelter and win the general public's support, influential (majority white) public advocates created a colorblind public identity for the homeless. Influential activist groups such as the Community for Creative Non-Violence (CCNV) in Washington DC and the National Coalition for the Homeless in New York City and Washington DC were instrumental in advocating for homeless rights, making homelessness a national problem, and omitting race from the discourse about homelessness (Jones 2016). Mitch Snyder, a former job counselor on Madison Avenue turned CCNV leader, Robert M. Hayes, a prominent Wall Street attorney and founder of the National Coalition for the Homeless (NCH), and Maria Foscarinis, NCH. inaugural national policy director and architect of the McKinney-Vento Act, were three of the most prominent national homeless advocates and the driving force behind bringing homelessness to the forefront of public consciousness (Gabbard et al. 2006; Foscarinis 2018). Snyder, Hayes, and Foscarinis were all white and middle-class and were able to use their social and political power to gain national attention on the issue of homelessness but did so by constructing colorblind narratives of homelessness. Each advocate used a combination of lawsuits, congressional hearings, mainstream media, and academic publications to shift the discourse around homelessness.

On 30 March 1987, Snyder was interviewed on a local Boston morning show. He was asked by the host, "Who is the homeless person?" Snyder responded:

The reality is that homeless people are everyone. They are you (referring to the white male television host). They are from every walk of life, every color, every age, every size is represented on the street. All those folks share something in common and it is only one thing - that one thing is that at one point in time, they needed help desperately because of some temporary or permanent disability, economic, mental or physical (short pause) something happened that caused them to need help and they didn't get it. (Martin Sheen and Mitch Snyder Interview with Good Day! 1987)

Snyder's response propagated the idea that everyone was equally susceptible to experiencing homelessness. His inclusion of the white, male, middle-class host in his response emphasized commonalities across racial lines between seemingly "everyday people" and those experiencing homelessness. Figure 1 illustrates my conceptualization of homeless advocates' public identity of the homeless based on Snyder, Hayes, Foscarinis' description of who became homeless and why. In addition to inserting white people into the public persona of homelessness, homeless advocates also characterized people experiencing displacement as willing workers deserving of compassion, calculating that the response from the government and the public would likely lead to federal support and public philanthropy. 
Traits

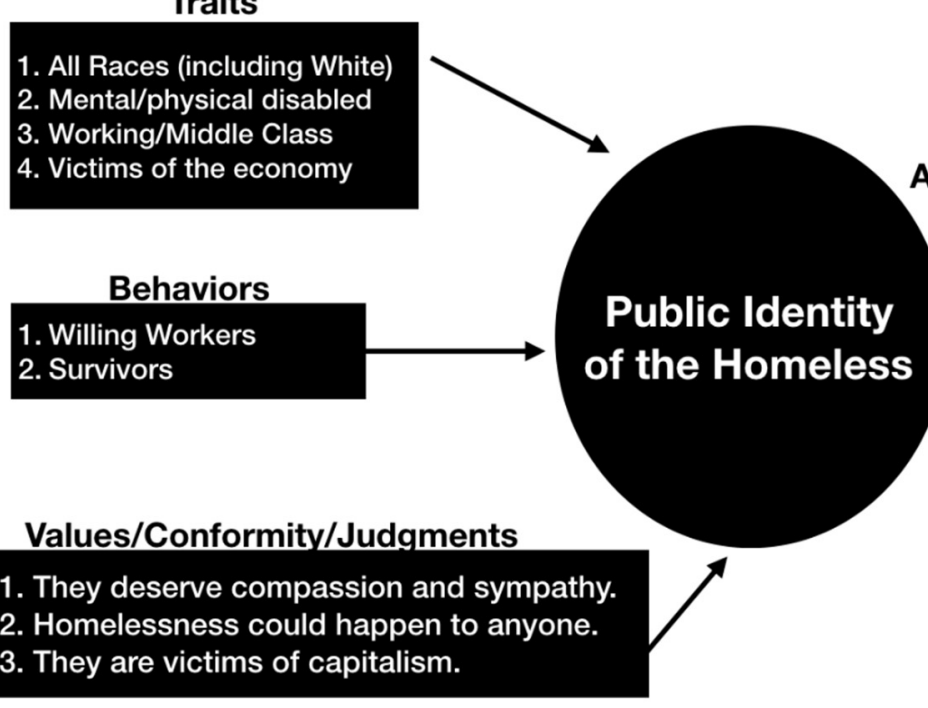

Public Support

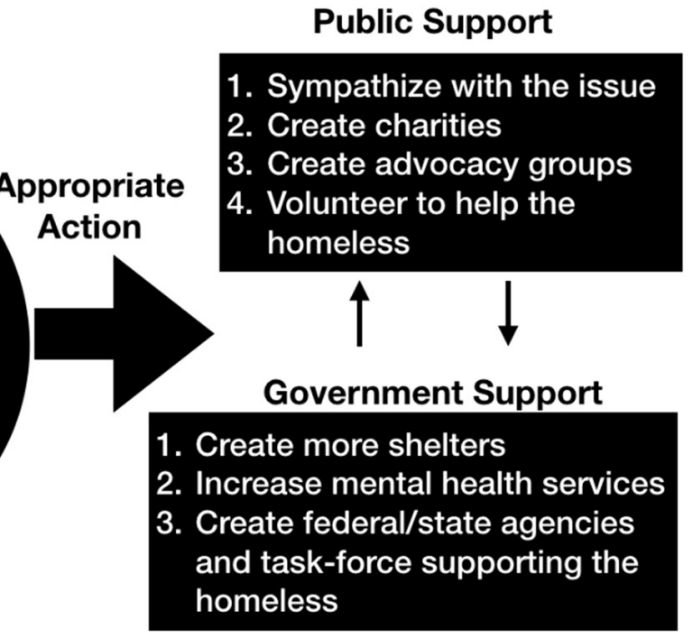

Conceptualized by Earl Edwards using Hancock, 2003

Figure 1. The everyday people public persona for the homeless.

\section{Methods of Disseminating a Colorblind Persona for the Homeless}

In order for a public persona to work effectively and shift people's perception of a political agenda related to a group of people, it must be broadcasted to a general population until the public persona becomes accepted as common knowledge (Hancock 2003). Robert Hayes, Mitch Snyder, and Maria Foscarinis utilized various disseminating methods, but all successfully raised the country's awareness of a colorblind homeless persona. Robert Hayes used Congress committee hearings and class lawsuits on behalf of the homeless to force homelessness into the political discourse. Hayes would select white men impacted by homelessness as tokens to go on national television or meet with politicians and share their unfortunate fall on the streets (Kolata 1989). For example, Hayes' first legal victory came at the hands of a class lawsuit (Callahan v. Carey) that began in 1979. Even though a reported 80 percent of people experiencing homelessness were Black in New York City (Brown 1981), Hayes legal case centered a white Irish man experiencing homelessness on a skid row in New York City. Hayes' selection of a white man to be the face of his lawsuit resulted in increased news coverage and led to politicians discussing homelessness with a white face. While he garnered a lot of public attention, Hayes would lament in an interview that news programs and congressional committees wanted to see "white middle class-people as homeless" to gain sympathy from "middle-America" (Kolata 1989).

Mitch Snyder used different approaches to promulgate a colorblind public persona for the homeless. Snyder became a public figure and used national news and celebrity (his and others) to disseminate the colorblind homeless public persona to the masses. Mitch Snyder led large demonstrations and slept with the homeless outside of the White House in Washington DC, which he referred to as "Reaganville." He became so popular, a television movie, Samaritan: The Mitch Snyder Story, was produced and aired in 1986, starring award-winning actor Martin Sheen as Snyder. In his film, demonstrations, and frequent news interviews, Snyder argued that the economy was the driving force behind homelessness, and any middle-class American could fall victim to it.

Maria Foscarinis echoed Snyder's economic root cause argument and used it in describing the root causes of homelessness. Foscarinis was the architect of the Homeless Personal Survival Act (which is the foundation of the McKinney-Vento Homeless Assistance Act) and was the most prominent figure lobbying US Congressmembers around homeless legislation. She leveraged her litigation experience and unique ability to collaborate with on-the-ground homeless organizers such as Synder and socially elite Republican 
and Democratic politicians to shape the national homeless agenda (Foscarinis 2018). When framing homelessness as a national issue, she pushed against the default narrative of individual failure on behalf of the homeless and moved the discourse towards a narrative of a public policy failure. Foscarinis' framing of the problem was significant because she was not only drafting the homeless legislation, she was contributing to the scholarship on the issue of homelessness through academic journals as well. For example, Foscarinis' 1991 publication "The Politics of Homeless: A Call to Action" listed housing and income as the two major structural issues causing homelessness (Foscarinis 1991). Below are two passages demonstrating her framing of the root causes of homelessness:

(Homelessness, when) viewed as a social rather than an individual phenomenon, homelessness is not mysterious nor are its causes difficult to fathom. Indeed, the growth of homelessness should be no surprise. It is the predictable result of government policies (p. 1233) ... Any national agenda for long-term solutions to homelessness must address its underlying causes. Given those causes, two basic areas should form the foundation of such an agenda: housing and income. (p. 1235)

Foscarinis, such as Snyder, framed homelessness as an issue rooted in class and economic inequities. While data points to the lack of affordable housing and the closing of highpaying factory jobs in large cities as key structural drivers to homelessness that could impact any working-class or middle-class family, she excluded housing and employment discrimination as concurrent drivers for the staggering and disproportionate number of Black people experiencing homelessness. Excluding racial discrimination within her structural framing of homelessness as a policy failure removed a significant barrier that may have impacted over fifty percent of the people experiencing homelessness.

Unlike the National Welfare Rights Organization (NWO) that had limited power to counter the government's public persona of the "Welfare Queen," homeless advocates such as Maria Foscarinis, Mitch Snyder, and Robert Hayes were able to succeed. NWO did not have the positional power or social capital as an organization ran by Black, poor women to garner sustained media coverage to shift the dominant narrative around welfare. However, Community for Creative Non-Violence and the National Coalition for the Homeless leaders used their positional power as white and middle-class advocates when arguing for homeless rights. While Hayes and Foscarinis used their power as prominent lawyers to uplift the voices of the homeless, Snyder became homeless and embodied what he believed the face of homelessness could be. It is important to note that this paper highlights Foscarinis, Synder, and Hayes as key figures in the framing of the "everyday people" persona of homelessness, however, many other people, organizations, and scholars also promoted a similarly race-neutral narrative of homelessness.

\section{Public Identity B: The Homeless as the Underclass}

While advocates sought to build a public identity deserving of compassion, political thought leaders and the federal government attempted to construct a public identity for homelessness that elicited disgust. Local and national politicians and social thought-leaders tried to establish a narrative where the "new homeless" were a growing part of the already established "underclass" persona within American society.

In the 1970s, the term "underclass" was a popular label used to describe Black citizens ages 18-35 years old who were "jobless, lacked salable skills and labeled social problems by the police, schools, employment and welfare agencies (Glasgow 1980, p. 1)". In addition to lacking the basic skills to survive in American society, those characterized as the "the underclass" lacked the will to change their circumstances and thereby chose to be a part of the underclass. Other racial-ethnic demographics (including white people) were also part of the underclass, but the public identity associated the underclass with poor, urban, Black people (Auletta 1982; Glasgow 1980; Jencks 1989). In addition, the characteristics of the underclass were differentiated by gender. Poor, young, Black women (primarily single mothers) in urban cities were bestowed the public identity of welfare queens (Jencks and 
Peterson 2001; Magnet 2000), and poor, young, Black men in urban cities were identified as "violent predators" (Dilulio 1989; Glasgow 1980; Jencks and Peterson 2001; Lemann 1986).

Political strategists and thought-leaders attempted to merge homelessness with the public identity of the "underclass" and emphasized their decision to live on the streets to avoid addressing issues on homelessness. For example, journalist and political strategist Myron Magnet, a prominent influencer of conservative social and economic policies of the 1980s, argued that the "common" homeless individual was, in fact, a 30-year-old Black male crack addict who committed violent crimes such as murder and rape (Magnet 2000). Magnet's description of the homeless aligned with the broader false narrative of the time, which labeled Black men as drug-addicted criminals (Alexander 2010). Under that guise of "The War of Drugs," the negative portrayal of Black men was spread through the media for mass consumption, ultimately leading to the mass incarceration of Black men. Connecting Black men to homelessness would potentially negate any sympathy from white Americans and portray the homeless as people to fear.

While Magnet portrayed homeless individuals as Black men, he associated homeless families with poor Black women. He asserted that the families experiencing homelessness were:

Headed by a subgroup of welfare mothers who haven't succeeded in keeping a roof over their children heads ... they live in welfare hotels and shelters, and they are homeless not in the sense of having been living on the street but rather ... they have declared themselves homeless-no one checks to see if they really arein order to get bumped to the head of the waiting list for permanent subsidized housing. (Magnet 2000, p. 83)

Magnet's description of homeless families was aligned with the public persona of the "welfare queen" and helped frame "homelessness" as a choice people made to avoid working (Collins 1998; Hancock 2003). Figure 2 is my conceptualization of the federal government's public identity of people experiencing homeless based on Magnet and conservative thought leaders of the time descriptions of the underclass. Ultimately, the goal of the Reagan administration and thought-leaders of the 1980s were to call upon existing, negative stereotypes of Black people to establish a public identity for homelessness that would seem morally unfit for public sympathy and government support. For example, when President Reagan was asked about the homeless epidemic in 1984, he responded, "people who are sleeping on the grates ... the homeless ... are homeless, you might say, by choice." While Reagan's suggestion that people chose to be on the street justified the federal government's decision to ignore homelessness and it aligned with the public persona of the underclass' decision to be delinquent, criminal, and houseless due to laziness rather than work and help themselves.

While conservative thought leaders and politicians such as Magnet and the Reagan administration, weaponized the "underclass" persona to cut social welfare programs and ignore the homeless, liberal politicians and thought leaders similarly promulgated the persona. For example, in 1981, Ken Auletta, an influential journalist for the reputable magazine The New Yorker wrote three articles defining the "underclass," thereby popularizing the term (Jencks 1989). Similarly, liberal policymakers such as Daniel Patrick Moniyan and Black scholars such as William Julius Wilson used the term "underclass" to create cultural arguments to justify the stagnation of some urban, poor Black people post the Black Freedom Movement of the 1960s (Robinson 2003; Wilson 1987). Thus, although the liberal rationale for using the persona may have differed from that of conservative leaders and influencers, it equally contributed to the persona's overall dissemination into public discourse. 


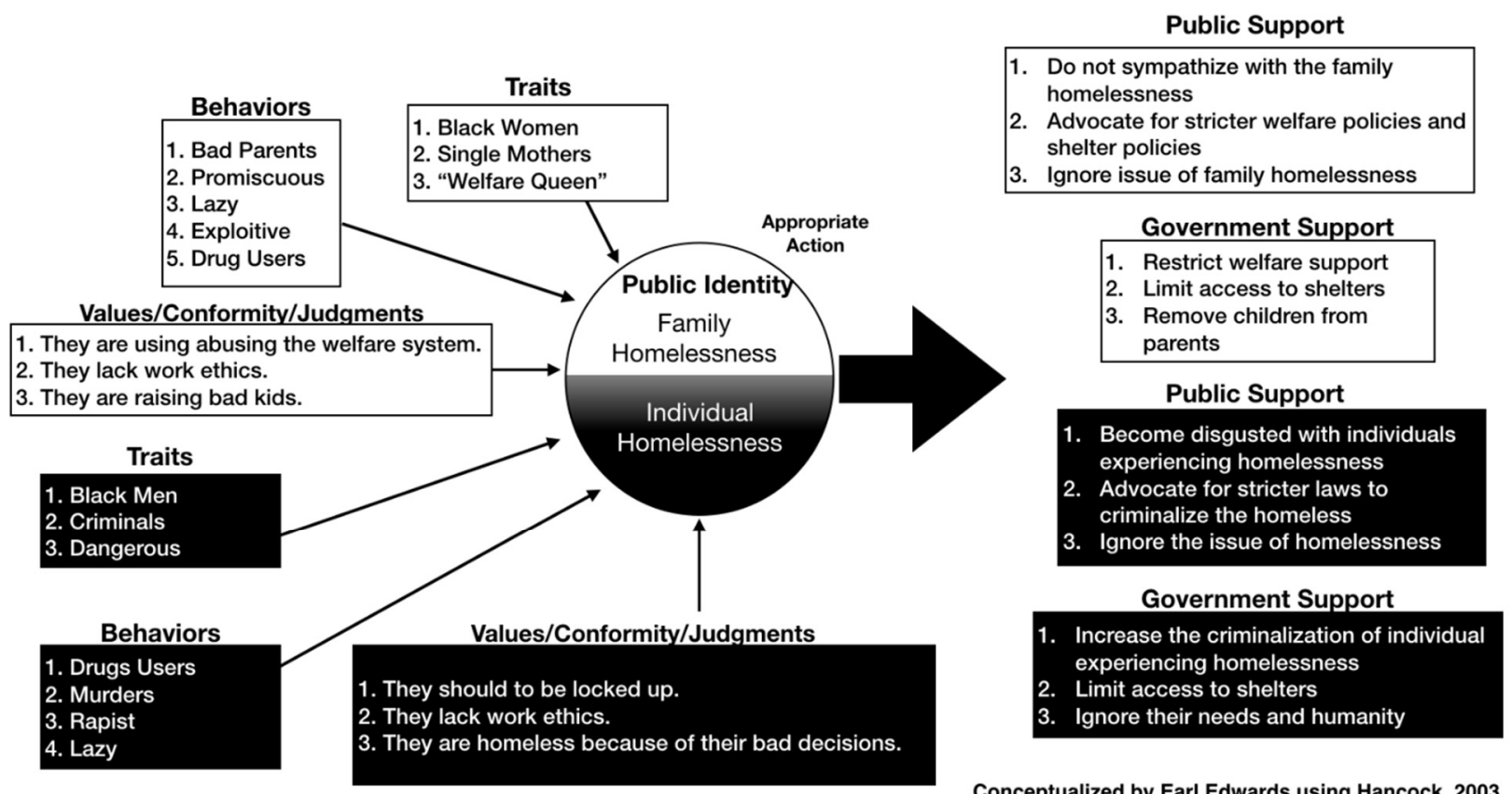

Figure 2. The underclass public persona for the homeless.

\section{The Creation and Consequences of a Dual Public Identity for the Homeless}

Traditionally, the Public Identity Framework only allows for one public persona to influence policies for a particular political agenda. I argue, however, that in the case of homelessness, both the "everyday people" and the "underclass" public personas for the homeless operated concurrently. I label this phenomenon as a dual public identity and define it as the concurrent use of a colorblind public persona and a racialized public persona to influence public policy, resulting in further marginalization of Black people and other disenfranchised communities. As conceptualized in Figure 3, while both personas of homelessness had contradictory approaches and different political agendas, they ultimately worked together to impact Black men, women, and children negatively.

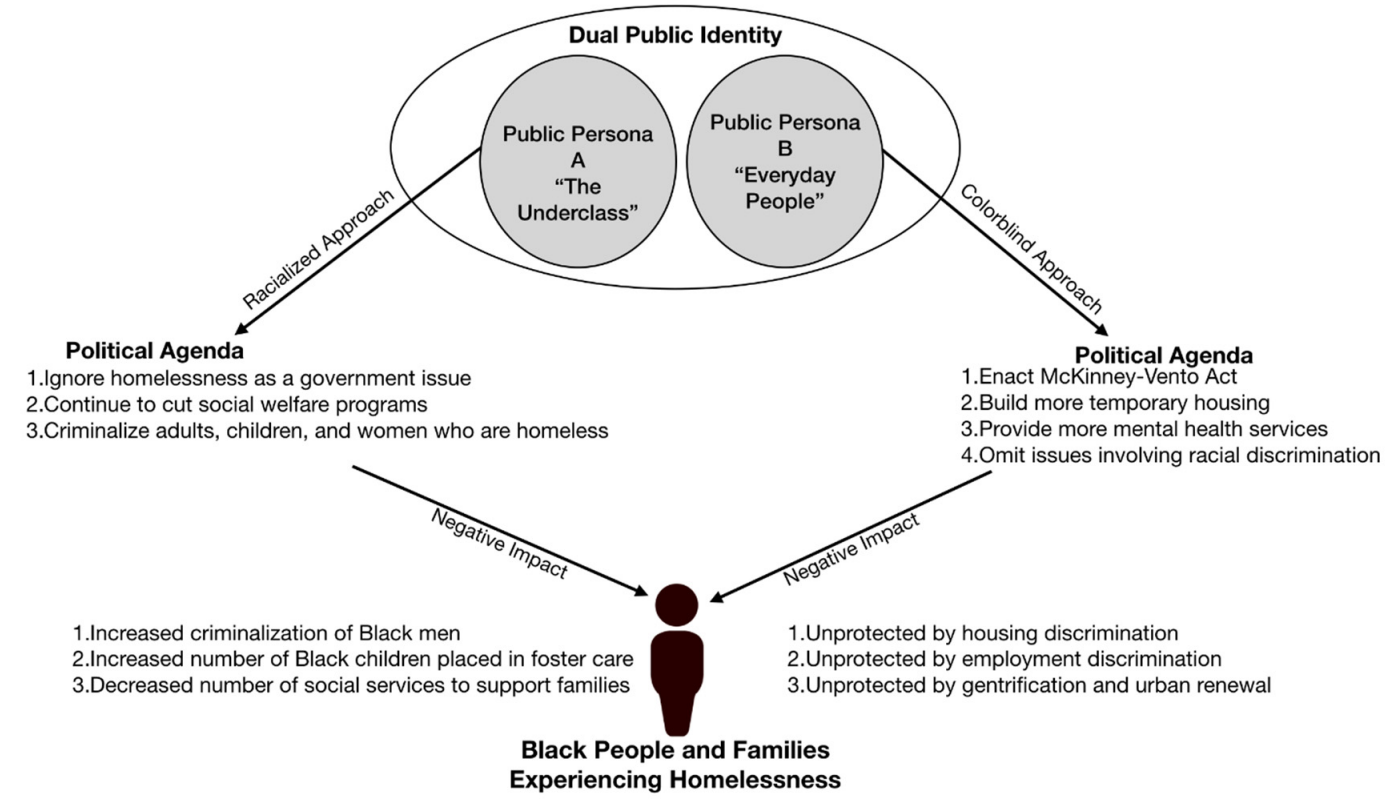

Figure 3. The dual public identity of the homeless. 
The "underclass" public persona used a racialized approach to enact a political agenda that attempted to (1) ignore homelessness as a government issue, (2) cut social welfare programs, and (3) criminalize homeless adults, children, and families. While the government failed to ignore homelessness completely, "the underclass" persona was broader than homelessness and was successful at cutting social welfare programs and criminalizing the poor and Black people. For example, the "underclass" public persona criminalized Black men via street policing and biased policies that cycled millions of Black men through the criminal justice system under the guise of "the war on drugs (Alexander 2010)." In the 1980s, approximately $60 \%$ of the individuals living on the streets report having been arrested either before or during their homeless experience (Redburn and Buss 1986; Snow et al. 1989), and Black men were often the demographic most negatively affected.

Similarly, policies criminalized and punished Black women by removing their children and controlling their reproductive rights. Black families were disproportionately targeted by the child welfare system based on characterizations of the underclass family as being dysfunctional and immoral. Black mothers were hyper-surveilled by the child welfare system and disproportionately reported for child neglect (Roberts 2002, 2011). As such, Black youth were stripped from their families and placed into foster care at higher rates than any other racial-ethnic group. Additionally, Black youth were the most likely demographic to age-out of the foster youth program at 18 years old. Most youth who age out of the foster-care system end up homeless within three years (Barth 1990). Moreover, Black women, especially those who were homeless and poor, were counseled by the federal and local government agencies to undergo sterilization (Roberts 1997).

Ultimately, the underclass narrative continued to funnel Black people into state institutions that created cycles of homelessness for them. As the "underclass" persona criminalized the homeless, the "everyday people" persona allowed homeless advocates to successfully push the McKinney-Vento Homeless Assistance Act to pass in Congress. While the "everyday people" narrative helped the MVA to pass, the colorblind frame of the policy proved ineffective at mitigating many effects of homelessness for Black people. Paradoxically, homeless advocates' efforts to pass legislation by disassociating Black faces from homelessness (intentionally or not) further marginalized Black people experiencing homelessness. The colorblind approach left Black Americans unprotected from the negative impacts of urban renewal (Johnson 2010), housing discrimination (Ross and Turner 2005), employment discrimination (Bound and Freeman 1992), and reverse redlining practices (Nier and Cyr 2010) and mass incarceration (Alexander 2010) that were already rampant before to 1980s.

For example, one compromise made in MVA was the explicit exclusion of "imprisoned" individuals from the policy's definition of homeless. Section $103 \mathrm{c}$ of the bill states, "homeless" or "homeless individual" does not include any individuals imprisoned or otherwise detained pursuant to an Act of the Congress or a State law" (The McKinney-Vento Homeless Assistance Act of 198742 U.S.C. § 11431, et seq 1987). This exclusion meant people incarcerated with no housing would lose any benefits and service continuity under MVA, a reality that disproportionately impacted Black people due to law enforcement racial profiling practices.

Despite best intentions to mitigate the effects of homelessness for all people, in practice, the "everyday people" public persona worked alongside the "underclass" public persona to disenfranchise Black people and promulgate cycles of homelessness. The "everyday people" agenda did provide Black people with better shelters and mental health services; however, the services did not impact Black people in the same way. White people experiencing homelessness were able to use the homeless shelters and additional health services to obtain permanent housing. Meanwhile, Black people stayed in shelters twice as long, and were the least likely to need the mental health services offered (Rocha et al. 1996). Black people's long and frequent episodes of homelessness were partially due to the "everyday people" persona's inability to address racial discrimination in the housing and employment market. A study analyzing the success rate of New York's Section 8 Rental 
Voucher program between 1985 and 1988 showed that Black voucher recipients were 30\% less likely to find housing using their voucher than white participants (Finkel and Kennedy 1992). Even when the study isolated race and controlled for income source, family size, and age, Black New Yorkers had lower success rates when trying to find subsidized housing. Black people's longer and more frequent episodes of homelessness re-enforced the false narrative of Black people being lazy and attempting to exploit the welfare system rather than working hard to find housing. Additionally, the longer Black people lived in shelters or on the streets, the more opportunities for them to be criminalized and shamed by the "underclass" persona of the homeless.

\section{Lessons Learned and Policy Implication}

The Dual Public Identity Framework allows researchers to critically analyze the use of public personas to frame public policies. While the creation of public identities for people experiencing homelessness occurred 30 years ago, the personas developed, and the policies created can inform policymakers and policy advocates today. Homeless advocates such as Mitch Snyder, Robert Hayes, and Maria Foscarinis provided critical contributions towards framing U.S. homelessness as a structural issue and they understood the MVA as a starting point (Foscarinis 1991, 2018). While their policy shifted the homeless discourse and led to a legislative milestone, policymakers, advocates, and researchers should learn from the unintended results of their policy framing. While the "Everyday people" public persona worked to pass critical legislation relatively quickly, excluding racial discrimination from the narrative of homelessness has had three dangerous consequences which still impact people experiencing homelessness today.

First, the race-neutral approach of the "Everyday people" public persona narrowed the scope of homelessness as a problem, thereby limiting potential solutions for addressing homelessness via public policy. Excluding specific racial-ethnic groups when addressing a social issue makes it nearly impossible to pass comprehensive policies that support the excluded group. For example, if the public persona of homelessness is a white man, fighting for homeless policies that include protections against racial housing discrimination becomes illogical. Racial housing discrimination does not universally impact people of different races who experience homelessness. Thus, it becomes difficult to pass policies addressing racial housing discrimination without specifically highlighting Black people. Current policymakers and advocates should recognize that a colorblind frame delegitimizes racial realities brought about by structural racism and racial discrimination.

The second unintended consequence of colorblind policies is that it becomes impossible to see racial disparities among subpopulations. The measures created by researchers and service providers to judge the implementation of the McKinney-Vento policy were built to look at homelessness in the aggregate of "Everyday people." While the McKinneyVento Act, and subsequent policies using the same frame, helped provide housing to many people experiencing homelessness, they did not identify outcome disparities between racial groups. Furthermore, mitigating racial disparities was not included as a measure for success, and discrepancies were rarely made public (Jones 2016). As a result, the data collected and analyzed to improve the implementation of the McKinney-Vento Act omitted racial outcomes, thereby preventing racial disparities from being seen. Current policymakers, advocates, and researchers should ensure their tools for assessing program and policy implementation disaggregates data by subpopulations, including race, gender, and other salient intersectional identities.

The third unintended consequence of using a colorblind public persona for homelessness is that the frame can work concurrently with racialized personas. Homeless advocates had a lot of influence in shaping the narrative of who was impacted by homelessness; however, it was not enough to completely negate the racial narratives of the federal government and the structural disparities embedded with housing and employments. The Dual Public Identity Framework (Figure 3) presented in this paper shows that race-neutral policies and public identities not only ignore Black people's root issues, but they also exacerbate the 
population's vulnerability. While the Dual Public Identity Framework was conceptualized to analyze homeless policies, it could be used by policymakers and advocates for several social issues for which they are attempting to create public identities. Public personas around drug enforcement, immigration policies, and public-school safety are a few examples of issues where a dual identity has been designed to support majority white populations while ignoring and criminalizing Black, Native American and other marginalized people.

The "everyday people" approach presented false solutions to solving homelessness for Black people, which justified the racialized public persona that criminalized them. For example, as mentioned earlier, if Black people stay in shelters twice as long as white people due to issues of housing discrimination that are being ignored, the false narrative that depicts Black people as lazy exploiters of the welfare system can be reinforced. The false narrative of the "underclass" would lead policymakers to attempt to "fix Black people's motivation" via stricter penalties rather than addressing their unique barriers. The premise that shelters and additional housing subsidies are the same safety net for Black and white adults and families assumes there is no racial bias within the housing market-an assumption that has never been true.

While this paper focuses on anti-Black racism, it is important to recognize that the Dual Public Identify Framework applies to other racialized groups and intersectional identities as well. For example, Native Americans are also an overly represented racial group in the U.S. homeless population (Henry et al. 2021). While Native Americans are also historically oppressed, their racialization in the U.S. is different than that of Black Americans, as such the impact of a color-blind public persona (Figure 3) would differ as well. Similarly, as Figure 2 demonstrates, the public persona or the persona's political impact may vary based on intersectional identities along the lines of race, class, gender, age, and sexual orientation. Black women's homeless public persona and their negative impacts were different than Black men's. However, while salient identities should be viewed in an intersectional manner, the racial analysis should not be removed from the framework. For example, while veterans and people who identify as LGBT are overrepresented in the homeless subpopulations and would not fit into the political framework of "Everyday people", an analysis absent of race can lead to the similar unintended consequences. For example, Black veterans are still overrepresented in the homeless population (Henry et al. 2021), and the type of criminalization that Black LGBT individuals experience on the streets and within institutions differs from that of their white peers (Snapp et al. 2015).

\section{Moving towards a Targeted Universal Approach to Homelessness}

An alternate approach to addressing homelessness is acknowledging the complexity that race plays in housing displacement and designing a targeted universal approach to addressing the problem. Unlike race-neutral universal methods, a targeted universal approach considers the impact of racism when addressing the aggregate problem and making specific goals based on the needs of different subpopulations (Powell 2008). A recent example of this targeted universal approach for homelessness can be seen in Los Angeles County, California. Los Angeles Homeless Service Authority (LAHSA) released a report that disaggregated and analyzed homeless service data by race. To create several targeted policy recommendations that specifically addressed the disproportionately high rate of Black homelessness, LAHSA collected qualitative data from service providers and Black people experiencing homeless. They also utilized quantitative administrative data (Los Angeles Homeless Services Authority 2018). Qualitative data consisted of individual interviews and focus groups, which accompanied with administrative data allowed for a more comprehensive understanding of Black people's experiences with homelessness. Black people with lived experience of homelessness helped to collect and analyze the data and create recommendations for the LAHSA report. LAHSA took a similar approach for veterans (Los Angeles Homeless Services Authority 2016) and women (Los Angeles Homeless Services Authority 2017) experiencing homelessness in previous years. While 
LAHSA is committed to ending homelessness for everyone, they are starting to recognize the importance of addressing the specific needs of racially marginalized populations.

Suppose policymakers and advocates can build from the contributions of former policy influencers that established homelessness as a structural problem and move towards a targeted universal frame that recognizes the unique challenges of Black and other marginalized populations. In that case, our policies can become more effective at closing disparity gaps while addressing aggregated problems. While a colorblind approach on social issues may allow for policies to be passed quicker or passed at all, a targeted universal approach recognizes the complexities of social issues and ensures that the needs of the most marginalized are addressed. To be clear, anti-Black structural racism is not the only driver contributing to homelessness, however, it is a significant problem that must be addressed by federal, state, and local governments explicitly if we ever want to truly end homelessness.

Funding: This research received no external funding.

Institutional Review Board Statement: Not applicable.

Informed Consent Statement: Not applicable.

Conflicts of Interest: The author declares no conflict of interest.

\section{Notes}

1 Only $\$ 720$ million was actually dispersed (see Gabbard et al. 2006; Foscarinis 2018).

\section{References}

Alexander, Michelle. 2010. The New Jim Crow: Mass Incarceration in the Age of Colorblindness. New York: New Press.

Auletta, Ken. 1982. The Underclass. New York: Random House Publishing Group.

Aviles de Bradley, Ann. 2015. From Charity to Equity_Race, Homelessness, and Urban Schools. New York: Teachers College Press.

Barth, Richard P. 1990. On Their Own: The Experiences of Youth after Foster Care. Child and Adolescent Social Work Journal 7: 419-40. [CrossRef]

Bound, John, and Richard B. Freeman. 1992. What Went Wrong? The Erosion of Relative Earnings and Employment Among Young Black Men in the 1980s. The Quarterly Journal of Economics 107: 201-32. [CrossRef]

Brown, Frank D. 1981. Homelessness among Blacks Now Epidemic. New York Amsterdam News (1962-1993), December 26.

Collins, Patricia Hill. 1990. Black Feminist Thought: Knowledge, Consciousness, and the Politics of Empowerment. New York: Routledge.

Collins, Patricia Hill. 1998. Fighting Words: Black Women and the Search for Justice. Minneapolis: U of Minnesota Press.

Crenshaw, Kimberle. 1989. Demarginalizing the Intersection of Race and Sex: A Black Feminist Critique of Antidiscrimination Doctrine, Feminist Theory and Antiracist Politics. University of Chicago Legal Forum 1989: 139.

Crenshaw, Kimberle. 1991. Mapping the Margins: Intersectionality, Identity Politics, and Violence against Women of Color. Stanford Law Review 43: 1241-99. [CrossRef]

Cumming, Elaine. 1974. Prisons, Shelters, and Homeless Men. Psychiatric Quarterly 48: 496-504. [CrossRef]

Dilulio, John J. 1989. The Impact of Inner-City Crime. The Public Interest 96: 28.

Edwards, Earl J. 2020. Young, Black, Successful, and Homeless: Examining the Unique Academic Challenges of Black Students Who Experienced Homelessness. Journal of Children and Poverty 26: 125-49. [CrossRef]

Finkel, Meryl, and Stephen D. Kennedy. 1992. Racial/Ethnic Differences in Utilization of Section 8 Existing Rental Vouchers and Certificates. Housing Policy Debate 3: 463-508. [CrossRef]

Foscarinis, Maria. 1991. The Politics of Homelessness: A Call to Action. American Psychologist 46: 1232-38. [CrossRef]

Foscarinis, Maria. 1996. The Federal Response: The Stewart B. McKinney Vento Homeless Assistance Act. In Homelessness in America. Edited by Jim Baumohl. Phoenix: Oryx Press, pp. 160-71.

Foscarinis, Maria. 2018. Strategies to Address Homelessness in the Trump Era: Lessons from the Reagan Years. Journal of Affordable Housing Volume 27: 22.

Fusaro, Vincent A., Helen G. Levy, and H. Luke Shaefer. 2018. Racial and Ethnic Disparities in the Lifetime Prevalence of Homelessness in the United States. Demography 55: 2119-28. [CrossRef] [PubMed]

Gabbard, Wesley Jay, Bryan Ford, and James Dean May. 2006. The Stewart B. McKinney Homeless Assistance Act: A Historical Overview. Journal of Social Distress and the Homeless 15: 99-115. [CrossRef]

Glasgow, Douglas G. 1980. The Black Underclass: Poverty, Unemployment, and Entrapment of Ghetto Youth. San Francisco: Jossey-Bass Publishers.

Hancock, Ange-Marie. 2003. Contemporary Welfare Reform and the Public Identity of the 'Welfare Queen'. Race, Gender E Class 10: 31-59. 
Henry, Meghan, Tanya De Sousa, Caroline Roddey, Swati Gayen, Thomas Joe Bednar, and Abt Associates. 2021. The 2020 Annual Homeless Assessment Report (AHAR) to Congress; Washington: The U.S. Department of Housing and Urban Development. Available online: https://www.huduser.gov/portal/sites/default/filespdf/2020-AHAR-Part-1.pdf/ (accessed on 10 September 2021).

Hombs, Mary Ellen. 1994. American Homelessness: A Reference Handbook, 2nd ed. Contemporary World Issues. Santa Barbara: ABC-CLIO.

Hopper, Kim, and Norweeta G. Milburn. 1996. Homelessness among African Americans: A Historical and Contemporary Perspective. In Homelessness in America. Edited by Jim Baumohl. Phoenix: Oryx Press, pp. 123-31.

Jencks, Christopher, and Paul E. Peterson. 2001. The Urban Underclass. Washington: Brookings Institution Press.

Jencks, Christopher. 1989. What Is the Underclass-and Is It Growing? Focus 12: 13.

Jencks, Christopher. 1995. The Homeless. Cambridge: Harvard University Press.

Johnson, Roberta Ann. 2010. African Americans and Homelessness: Moving Through History. Journal of Black Studies 40: 583-605. [CrossRef]

Jones, Marian Moser. 2015. Creating a Science of Homelessness During the Reagan Era. The Milbank Quarterly 93: 139-78. [CrossRef] [PubMed]

Jones, Marian Moser. 2016. Does Race Matter in Addressing Homelessness? A Review of the Literature. World Medical E Health Policy 8: 139-56. [CrossRef]

Khadduri, Jill, Dennis Culhane, and Associates Inc. 2007. The Annual Homeless Assessment Report to Congress. Washington: The U.S. Department of Housing and Urban Development, Available online: http:/ / www.ssrn.com/abstract=1680873 (accessed on 10 September 2021).

Kolata, Gina. 1989. Twins of the Streets: Homelessness and Addiction: Twins of the Streets: Homelessness and Addiction. New York Times, May 22.

Lemann, Nicholas. 1986. The Origins of the Underclass. Atlantic Magazine Archive 258: 54-68.

Levinson, David, ed. 2004. Encyclopedia of Homelessness. Thousand Oaks: Sage Publications.

Levitas, Mitchel. 1990. Homeless in America. The New York Times. June 10. Available online: https:/ /www.nytimes.com/1990/06/10 /magazine/homeless-in-america.html (accessed on 10 September 2021).

López, Ian Haney. 2015. Dog Whistle Politics: How Coded Racial Appeals Have Reinvented Racism and Wrecked the Middle Class. Reprint edition. Oxford: Oxford University Press.

Los Angeles Homeless Services Authority. 2016. Los Angeles County Veteran Homelessness Dashboard and Methodology Document. Los Angeles: Los Angeles Homeless Services Authority, Available online: https:/ / www.lahsa.org/documents?id=1485-los-angelescounty-veteran-homelessness-dashboard-methodology-document (accessed on 10 September 2021).

Los Angeles Homeless Services Authority. 2017. Report and Recommendations of the Ad Hoc Committee on Women E Homelessness. Los Angeles: Los Angeles Homeless Services Authority, Available online: https://www.lahsa.org/documents?id=1586-ad-hoccommittee-on-women-and-homelessness-report-and-recommendations.pdf (accessed on 10 September 2021).

Los Angeles Homeless Services Authority. 2018. Report and Recommendations of the Ad Hoc Committee on Black People Experiencing Homelessness. Los Angeles: Los Angeles Homeless Services Authority, Available online: https://www.lahsa.org/documents?id= 2823-report-and-recommendations-of-the-ad-hoc-committee-on-black-people-experiencing-homelessness.pdf (accessed on 10 September 2021).

Lubiano, Wahneema. 1992. Black Ladies, welfare queens and state minstrels: Ideological war by narrative means. In Raceing Justice, Engendering Power: Essays on Anita Hill, Clarence Thomas and the Construction of Social Identity. Edited by Toni Morrison. New York: Pantheon.

Mackie, Marlene. 1973. Arriving at 'Truth' by Definition: The Case of Stereotype Inaccuracy. Social Problems 20: 431-47. [CrossRef]

Magnet, Myron. 2000. The Dream \& the Nightmare: The Sixties Legacy to the Underclass. New York: Encounter Books.

Martin Sheen and Mitch Snyder Interview with Good Day! 1987. Good Day! Boston: WCVB-TV, Available online: https://www. youtube.com/watch?v=qy0Gso6FcSw (accessed on 10 September 2021).

National Alliance to End Homelessness. 2019. Demographic Data Project Part III: Race, Ethnicity, and Homelessness. Available online: https:/ / endhomelessness.org/demographic-data-project-race/ (accessed on 10 September 2021).

Nier, Charles L., III, and Maureen R. St. Cyr. 2010. A Racial Financial Crisis: Rethinking the Theory of Reverse Redlining to Combat Predatory Lending under the Fair Housing Act. Temple Law Review 83: 941-78.

Olivet, Jeffrey, Catriona Wilkey, Molly Richard, Marc Dones, Julia Tripp, Maya Beit-Arie, Svetlana Yampolskaya, and Regina Cannon. 2021. Racial Inequity and Homelessness: Findings from the SPARC Study. The ANNALS of the American Academy of Political and Social Science 693: 82-100. [CrossRef]

Paul, Dereck W., Kelly R. Knight, Pamela Olsen, John Weeks, Irene H. Yen, and Margot B. Kushel. 2020. “Racial Discrimination in the Life Course of Older Adults Experiencing Homelessness: Results from the HOPE HOME Study". Journal of Social Distress and Homelessness 29: 184-93. [CrossRef]

Powell, John A. 2008. Post-Racialism or Targeted Universalism. Denver University Law Review 86: 23.

Redburn, F. Stevens, and Terry F. Buss. 1986. Responding to America's Homeless: Public Policy Alternatives. Westport: Greenwood Publishing Group.

Roberts, Dorothy E. 1997. Killing the Black Body: Race, Reproduction, and the Meaning of Liberty. New York: Vintage. 
Roberts, Dorothy E. 2011. Prison, Foster Care, and the Systemic Punishment of Black Mothers Symposium: Overpoliced and Underprotected: Women, Race, and Criminalization: I. Establishing the Framework. UCLA Law Review 59: $1474-501$.

Roberts, Dorothy. 2002. Shattered Bonds: The Color of Child Welfare. New York: Basic Books.

Robinson, Dean E. 2003. 'The Black Family' and US Social Policy: Moynihan's Unintended Legacy? Revue Francaise Detudes Americaines 97: 118-28. [CrossRef]

Rocha, Cynthia, Alice Johnson, Kay Young McChesney, and William Butterfield. 1996. Predictors of Permanent Housing for Sheltered Homeless Families. Families in Society. The Journal of Contemporary Social Services 77: 50-57. [CrossRef]

Ross, Stephen L., and Margery Austin Turner. 2005. Housing Discrimination in Metropolitan America: Explaining Changes between 1989 and 2000. Social Problems 52: 152-80. [CrossRef]

Rossi, P. H. 1990. The Old Homeless and the New Homelessness in Historical Perspective. The American Psychologist 45: 954-59. [CrossRef]

Snapp, Shannon D., Jennifer M. Hoenig, Amanda Fields, and Stephen T. Russell. 2015. Messy, Butch, and Queer: LGBTQ Youth and the School-to-Prison Pipeline. Journal of Adolescent Research 30: 57-82. [CrossRef]

Snow, David A., Susan G. Baker, and Leon Anderson. 1989. Criminality and Homeless Men: An Empirical Assessment. Social Problems 36: 532-49. [CrossRef]

The McKinney-Vento Homeless Assistance Act of 198742 U.S.C. § 11431, et seq. 1987. Available online: https://www.govinfo.gov / content/pkg/STATUTE-101/pdf/STATUTE-101-Pg482.pdf (accessed on 10 September 2021).

Wilson, William Julius. 1987. The Truly Disadvantaged: The Inner City, the Underclass, and Public Policy. Chicago: University of Chicago Press. 